кОШикОВ Д.о.

\title{
ФУНКЩЇ ЯК СКЛАДНИК КОМПЕТЕНЦЇ̈ МІНІСТЕРСТВА РОЗВИТКУ ЕКОНОМІКИ, ТОРГІВЛІ ТА СІЛЬСЬКОГО ГОСПОДАРСТВА УКРАЇНИ У СФЕРІ ЗАБЕЗПЕЧЕННЯ ЕКОНОМІЧНОЇ БЕЗПЕКИ ДЕРЖАВИ
}

\begin{abstract}
У статті наголошено на тому, що вищі органи державної влади наділені широкими повноваженнями в конкретних сферах нормотворення (Верховна Рада України), правозастосування (Кабінет Міністрів України), правоохорони (суди, органи прокуратури, Антимонопольний комітет України). У зв'язку з цим обгрунтовано, що центральні органи виконавчої влади, зокрема Міністерство розвитку економіки, торгівлі та сільського господарства України, на відміну від вищих органів державної влади, наділені комплексною компетенцією, тобто мають повноваження як у напрямах нормотворення, правозастосування, так і у правоохоронному напрямі. 3'ясувавши зміст та складові елементи поняття «компетенція», визначили компетенцію центральних органів виконавчої влади в межах реалізації державної політики у сфері забезпечення економічної безпеки держави, до яких насамперед необхідно відносити Міністерство розвитку економіки, торгівлі та сільського господарства України. До завдань Міністерства розвитку економіки, торгівлі та сільського господарства України як структурного елементу його компетенції у сфері забезпечення економічної безпеки держави запропоновано віднести забезпечення формування та реалізацію державної цінової політики, державної промислової політики, підприємництва, публічних закупівель, інноваційної політики, сільського господарства, агропромислового виробництва, інтелектуальної власності, торгівлі та побутових послуг, промислової безпеки, управління об'єктами державної власності, корпоративними правами держави, державними інвестиціями державного матеріального резерву. Автором встановлено та охарактеризовано окремі структурні елементи компетенції Міністерства розвитку економіки, торгівлі та сільського господарства України у сфері забезпечення економічної безпеки держави, такі як предмет відання, який обмежується сферою національної економічної безпеки; повноваження; функції (нормативна, методична, аналітична, організаційна, координаційна, мобілізаційна, охоронна, а також функції планування, прогнозування, регулювання, моніторингу).

Ключові слова: компетенція, предмет відання, повноваження, функиї, юридична відповідальність, економічна безпека, державна політика, иентральні органи виконавчої влади, Міністерство розвитку економіки, торгівлі та сільського господарства України.
\end{abstract}

It is emphasized that the higher bodies of state power are endowed with broad powers in specific spheres of rulemaking (Verkhovna Rada of Ukraine), law enforcement (Cabinet of Ministers of Ukraine), law enforcement (courts, prosecutor's offices, Antimonopoly Committee of Ukraine). In this regard, it is substantiated that the central executive bodies, in particular the Ministry of Development of Economy, Trade and Agriculture of Ukraine, unlike the higher bodies of state power, are vested with complex competence that is, they have powers both in the areas of rulemaking, enforcement and in law enforcement direction. Having clarified the content and constituent elements of the concept of "competence", the competence of the central executive authorities within the implementation of state policy in the sphere of ensuring the economic security of the state to which the Ministry of Economic Development, Trade and Agriculture of Ukraine should be referred is determined. The tasks of the Ministry of Economic Development,

( ) КОШИКОВ Д.О. - кандидат юридичних наук, старший викладач кафедри поліцейської діяльності та публічного адміністрування (Харківський національний університет внутрішніх справ) 
Trade and Agriculture of Ukraine, as a structural element of its competence in the sphere of ensuring the economic security of the state, are proposed to ensure the formation and implementation of: the state price policy; state industrial policy; entrepreneurship; public procurement; innovation policy; Agriculture; agricultural production; intellectual property; trade and domestic services; industrial safety; management of objects of state property, corporate rights of the state; state investments of the state material reserve. The author establishes and characterizes certain structural elements of the competence of the Ministry of Economic Development, Trade and Agriculture of Ukraine in the sphere of ensuring the economic security of the state: subject matter, which is limited to the sphere of national economic security; powers; powers; functions (regulatory, methodological, analytical, organizational, coordination, mobilization, security, as well as functions of planning, forecasting, regulation, monitoring).

Key words: competence, subject matter, authority, functions, legal responsibility, economic security, state policy, central executive bodies, the Ministry of Economic Development, Trade and Agriculture of Ukraine.

Вступ. Не менш важливою за формування державної політики у сфері економічної безпеки держави $є$ ії реалізація, що покладається насамперед на центральні органи виконавчої влади. Перед ними ставляться конкретні завдання щодо розроблення локальних планів, стратегій, вирішення певного переліку проблем та вжиття заходів задля стабілізації рівня економічної безпеки. Така діяльність центральних органів виконавчої влади обмежується рамками, визначеними вищими органами державної влади, зокрема, в концепції та загальному плані реалізації державної політики у сфері забезпечення економічної безпеки держави. Зі свого боку центральні органи виконавчої влади самостійно вживають низку запланованих заходів, а також організовують їх виконання власними підрозділами, координують роботу органів місцевого самоврядування у зазначеному напрямі, а також за необхідності залучають громадськість. Таким чином, якщо вищі органи державної влади переважно працюють у напрямі вироблення уніфікованої державної політики, зокрема у сфері забезпечення економічної безпеки, то центральні органи виконавчої влади є основними суб'єктами її реалізації.

Тема компетенції органів державної та виконавчої влади, а також іiї структури посідає центральне місце у дослідженнях представників правової науки (Д.Н. Бахрах, Н.А. Богданова, В.С. Нерсесянц, Н.І. Панов, Б.В. Россинський, О.Ф. Скакун, Ю.Н. Старилов), адже саме за допомогою компетенції зазначені органи здійснюють управління в усіх соціально-важливих сферах. Разом із загальною характеристикою компетенції та ії структури вченими в різних галузях права також проводились спеціалізовані дослідження в напрямах діяльності органів виконавчої влади (Н.О. Армаш, В.В. Гарбузов, В.О. Криворучко, О.Д. Крупчан). Водночас у сучасній юридичній науці відсутні комплексні праці щодо визначення компетенції та функцій центральних органів виконавчої влади, зокрема Міністерства розвитку економіки, торгівлі та сільського господарства України (далі-Мінекономіки), в тому числі в одному з найважливіших питань загальнодержавного значення, а саме реалізації державної політики у сфері забезпечення економічної безпеки держави.

Постановка завдання. Метою статті є визначення одного з елементів компетенції центральних органів державної влади у сфері забезпечення економічної безпеки держави на прикладі Мінекономіки як одного з основних органів у зазначеній сфері, а саме функцій.

Результати дослідження. У загальному розумінні слово «компетенція» має декілька значень, котрі пов'язані з повноваженнями, правами та обов'язками конкретного суб'єкта, наданих йому для виконання поставлених перед ним завдань і покладених перед ним обов'язків. Під компетенцією, як правило, розуміють «повноваження, надані законом, статутом або іншим актом конкретному органу або посадовій особі; знання і досвід у певній галузі» [1, с. 613]; «добру обізнаність із чим-небудь» або «коло повноважень певної організації, особи» [2, с. 560; 3 , с. 235]. Це найпоширеніші визначення, котрі можна знайти в тлумачних та енциклопедичних словниках української мови. Слід підкреслити, що такі визначення $є$ нейтральними та не відображають специфіку ані політичної, ані юридичної, ані будь-якої іншої сфери, а у їх змісті прослідковується зв'язок компетенції з правами, наданими суб' єктам для реалізації їх повноважень, що дає змогу розглядати компетенцію як усталену юридичну категорію.

Компетенція в правовій доктрині найчастіше використовується для визначення складового елементу правового статусу органу державної влади [4, с. 97-98; 5, с. 48; 6, с. 376] який уособлює: 
1) «сукупність предметів ведення, прав і обов'язків державного органу, посадової особи, громадської організації» [7, с. 325] («Популярний юридично-енциклопедичний словник»);

2) «визначену і закріплену законом або іншим нормативним актом сукупність повноважень посадової особи або державного органу» [8, с. 62] («Словник термінів 3 теорії держави та права»);

3) «чітко визначені нормами права напрями діяльності (повноваження) державного органу (посадової особи), в основі яких лежать конкретні права та обов'язки» [9, с. 60] (за В.В. Гарбузом);

4) «закріплену законом (або іншим нормативним актом) сукупність його владних повноважень (прав і обов'язків), юридичної відповідальності і предмета відання (предмет діяльності, функціональне призначення)» [10, с. 363] (за О.Ф. Скакун).

Деякі вчені, наприклад Н.А. Богданова, Д.Н. Бахрах, Б.В. Россинський та Ю.Н. Старилов, відносять до елементів компетенції юридичну відповідальність [11, с. 190; 12, с. 17], що може бути обгрунтовано, на нашу думку, лише тоді, коли цей елемент розглядається як обов'язок суб'єкта нести відповідальність за порушення норм чинного законодавства. 3'ясувавши зміст та складові елементи поняття «компетенція», перейдемо до визначення компетенції центральних органів виконавчої влади в межах реалізації державної політики у сфері забезпечення економічної безпеки держави, до яких насамперед необхідно відносити Мінекономіки.

Центральні органи виконавчої влади, зокрема Мінекономіки, на відміну від вищих органів державної влади, наділені комплексною компетенцією, тобто мають повноваження як у напрямах нормотворення, правозастосування, так і в правоохоронному напрямі. Тоді як вищі органи державної влади наділені широкими повноваженнями в конкретних сферах нормотворення (Верховна Рада України), правозастосування (Кабінет Міністрів України (далі - КМ України)), правоохорони (суди, органи прокуратури, Антимонопольний комітет України), зміст діяльності органів виконавчої влади, як вважає В.О. Криворучко, полягає у «здійсненні державного управління. Органи виконавчої влади розробляють основні напрями соціально-економічної політики держави, її обороноздатності, безпеки, забезпечення громадського порядку та організують їх здійснення; організують управління державною власністю; виробляють заходи 3 проведення зовнішньої політики і виконують інші функції, покладені законодавством країни» [13, с. 95]. Схожої позиції дотримується К.Г. Волинка, акцентуючи увагу на тому, що така діяльність є державно-управлінською [14, с. 106].

Погоджуємось із тим, що компетенцію Мінекономіки переважно складають повноваження кожного з таких суб'єктів, а також їх предмет відання, завдання, функції та юридична відповідальність. Враховуючи специфіку цього дослідження, а саме сферу забезпечення економічної безпеки держави, вважаємо, що саме вона буде предметом відання, а також загальною метою для центральних органів виконавчої влади. Інші елементи компетенції, такі як повноваження, завдання, функції та юридична відповідальність, для кожного конкретного суб’єкта мають бути визначені окремо на підставі аналізу основного нормативно-правового акта, що регламентує його діяльність.

Завдання Мінекономіки закріплені в п. 3 Положення про Міністерство економічного розвитку і торгівлі України, затвердженого Постановою КМ України від 20 серпня 2014 року № 459 [15], причому розміщені вони в алогічному порядку. Йдеться про структурну побудову зазначеного пункту, котрий поділено на п'ять підпунктів, які здебільшого зведені до формування та реалізації державної політики в різних сферах переважно економічного характеру, тому законодавчо закріплена класифікація завдань є незрозумілою. Окрім того, деякі з перелічених сфер дублюють одна одну, зокрема сфери державних і публічних закупівель. Річ в тім, що терміни «державні закупівлі» та «сфера державних закупівель» були актуальними у період дії Закону України «Про здійснення державних закупівель», який «встановлює правові та економічні засади здійснення закупівель товарів, робіт і послуг за державні кошти» [16]. Цей Закон втратив чинність 20 квітня 2014 року у зв'язку з прийняттям іншого, а саме Закону України «Про публічні закупівлі», що «установлює правові та економічні засади здійснення закупівель товарів, робіт і послуг для забезпечення потреб держави та територіальної громади» [17].

Отже, сьогодні замість поняття «державні закупівлі» доцільно використовувати інше, а саме «публічні закупівлі», з огляду на те, що за своїм змістом ці поняття є ідентичними, тому одночасне закріплення обох вказаних понять в п. 3 зазначеного положення є неактуальним і не відповідає сучасній термінології законодавства. Окрім того, державна політика економічного розвитку включає сфери підприємництва, ціноутворення, промисловості, сільського господарства тощо, тому не повинна виокремлюватись у самостійний напрям, а власне реалізація державної цінової політики включає здійснення контрольної діяльності за цінами. Зазначене ускладнює 
розуміння завдань Мінекономіки і як самостійної категорії, і як структурного елементу компетенції, а дублювання та відсутність систематизації завдань взагалі не дають можливості сформувати об'єктивне уявлення про діяльність Мінекономіки. Це той випадок, про який говорять «все і нічого», оскільки з такого викладення дійсно майже нічого не зрозуміло. Зважаючи на необхідність визначення конкретних завдань Мінекономіки, вважаємо за можливе систематизувати та викласти їх у п. 3 Положення про Міністерство економічного розвитку і торгівлі України, затвердженого Постановою КМ України від 20 серпня 2014 року № 459, таким чином.

3. Основними завданнями Мінекономіки $є$ :

1) забезпечення формування та реалізації:

- державної політики економічного розвитку у сферах державної цінової політики; державної промислової політики; підприємництва; публічних закупівель; інноваційної політики; сільського господарства; агропромислового виробництва; інтелектуальної власності; торгівлі та побутових послуг; промислової безпеки;

- державної політики соціального розвитку у сферах надання адміністративних послуг; захисту прав споживачів; зайнятості населення, трудової міграції, державного замовлення на підготовку фахівців, наукових, науково-педагогічних та робітничих кадрів, підвищення кваліфікації та перепідготовку кадрів; охорони гігієни праці; соціального діалогу; державно-приватного партнерства; поводження з вибуховими матеріалами; здійснення державного гірничого нагляду; туризму та курортів;

- єдиної зовнішньоекономічної політики та контролю державного експорту, а також вирішення питань, пов'язаних з економічним і соціальним співробітництвом України з СС; залученням міжнародної технічної допомоги; інтеграцією національної економіки у світову економіку; співробітництвом зі Світовою організацією торгівлі (СОТ);

- державної політики у сфері управління об’єктами державної власності, корпоративними правами держави; державними інвестиціями державного матеріального резерву;

- державної політики у галузі статистики на засадах професійної незалежності та самостійності органів державної статистики щодо розроблення й затвердження нормативно-правових актів;

- державної політики у сфері організації та контролю за виготовленням цінних паперів, документів суворої звітності;

- державної політики технічного регулювання, стандартизації, дозвільної системи, ліцензування, метрології та метрологічної діяльності.

До завдань Мінекономіки як структурного елементу його компетенції у сфері забезпечення економічної безпеки держави можемо віднести забезпечення формування та реалізації державної цінової політики; державної промислової політики; підприємництва; публічних закупівель; інноваційної політики; сільського господарства; агропромислового виробництва; інтелектуальної власності; торгівлі та побутових послуг; промислової безпеки; управління об'єктами державної власності, корпоративними правами держави; державними інвестиціями державного матеріального резерву.

Подібно до завдань Мінекономіки його нормативно закріплені повноваження також характеризуються множинністю (їх налічується більше 350), окрім того, вони також містять певні термінологічні помилки. У пп. 95 п. 4 Положення про Міністерство економічного розвитку і торгівлі України, затвердженого Постановою КМ України від 20 серпня 2014 року № 459 [15], одночасно застосовуються ідентичні за змістом терміни державних та публічних закупівель, причому в деяких підпунктах (пп. пп. 102, 105, 108) законодавець використовує лише термін публічних, а не державних закупівель. У зв'язку з цим вважаємо за необхідне викласти зазначену норму в такій редакції.

95) здійснює нормативно-правове забезпечення державного регулювання у сфері державних та публічних закупівель; ...

99) надає роз'яснення щодо застосування законодавства у сфері публічних закупівель;... закупівель;

$103)$ розробляє примірні навчальні програми з питань організації та здійснення публічних

104) забезпечує функціонування безоплатного веб-порталу уповноваженого органу з питань публічних закупівель.

Систематичне тлумачення п. 4 Положення про Міністерство економічного розвитку і торгівлі України, затвердженого Постановою КМ України від 20 серпня 2014 року № 459 [15], дає можливість віднести до повноважень, пов'язаних із забезпеченням економічної безпеки, таке: 
- надає пропозиції щодо вдосконалення правових актів, розробляє їх проєкти, зокрема у сферах бюджетного та податкового законодавства; приймає підзаконні нормативно-правові акти з питань економічного характеру, зокрема тих, що створюють правову основу діяльності, пов'язаної із забезпеченням економічної безпеки держави;

- аналізує стан та тенденції економічного й соціального розвитку держави, секторів та галузей економіки, регіонів; інструментів валютно-курсової, грошово-кредитної політики на розвиток економіки, робить висновки щодо їх ефективності; впливу ринку фінансових і банківських послуг на економічний розвиток держави; економічної ситуації у соціально-гуманітарній сфері та оцінки впливу заходів державної політики у зазначеній сфері на економічний розвиток;

- здійснює середньо- та короткострокове прогнозування економічного й соціального розвитку України, надає організаційне методичне забезпечення з аналогічного планування на рівні областей, районів і міст, а також безпосереднього виконання таких планів і програм; можності;

- розробляє заходи щодо підвищення рівня національної економіки, їі конкурентоспро-

- бере участь у формуванні та реалізації державної фінансової, бюджетної, податкової, митно-тарифної та науково-технічної політики;

- вирішує питання, пов'язані із забезпеченням промислового сектору економіки, зокрема, в науково-технічному аспекті та оборонно-промисловому комплексі;

- регулює та координує функціонування інвестиційної сфери; сфери економічної конкуренції; агропромислового виробництва; сільського господарства; цивільного захисту й обмеження монополізму; індустріальних парків; механізму економічної безпеки держави, детінізації економіки та відповідних заходів;

- здійснює розрахунок і моніторинг індикаторів продовольчої безпеки;

- забезпечує в установленому порядку захист економічних прав і законних інтересів України, їі суб'єктів господарювання, а також здійснює відповідні розслідування у визначеному законом порядку, зокрема антидемпінгові, антисубсидиційні та спеціальні розслідування;

- здійснює мобілізаційну підготовку національної економіки, координує роботу зі створення, розвитку, утримання, передачі, ліквідації та реалізації мобілізаційних потужностей, зокрема задля вирішення питань у сфері захисту населення й територій від надзвичайних ситуацій техногенного та природного характеру.

Висновки. Викладені вище узагальнені повноваження Мінекономіки у сфері забезпечення економічної безпеки держави дали можливість сформулювати такі його функції:

1) нормативна функція полягає в тому, що зазначений орган приймає велику кількість підзаконних нормативно-правових актів задля організації та забезпечення вжиття заходів, спрямованих на підвищення економічної безпеки держави, а також вносить пропозиції та розробляє проєкти законодавчих актів у зазначеній сфері;

2) функція планування уособлює діяльність щодо короткострокового та середньострокового планування розвитку економічного сектору держави, зокрема на регіональному та місцевому рівнях;

3) функція прогнозування випливає з повноважень Мінекономіки щодо здійснення економічного й соціального розвитку країни;

4) методична функція пов'язана 3 функцію планування та функцією прогнозування, оскільки Мінекономіки як центральний орган виконавчої влади, що реалізує державну політику у сфері забезпечення економічної безпеки держави, надає методичні вказівки;

5) аналітична функція передбачає здійснення аналізу та систематизації даних, отриманих у результаті такого аналізу прогресивних тенденцій національної економіки та взагалі їі реального стану, методів і способів, що використовуються для вдосконалення валютно-курсової, грошово-кредитної політики;

6) організаційна функція випливає 3 повноважень щодо організації та вжиття заходів, спрямованих на підвищення стабільності та економічного рівня держави та забезпечення ії безпеки, зокрема продовольчої, як самостійно, так і у співпраці з іншими органами державної виконавчої влади та громадськими інституціями;

7) функція регулювання стосується регуляторної діяльності в інвестиційній сфері, сферах економічної конкуренції, агропромислового виробництва, сільського господарства, цивільного захисту, обмеження монополізму тощо;

8) координаційна функція проявляється в тому, що Мінекономіки є суб'єктом координації діяльності виконавчих органів державної влади в напрямі розбудови економічної сфери держави, 
забезпечення іiї безпеки, детінізації економіки, а також забезпечує соціальний діалог та співпрацю $з$ громадськими інституціями;

9) мобілізаційна функція випливає з повноважень, які стосуються акумулювання всіх економічних потужностей держави за необхідності (наприклад, виникнення надзвичайних ситуацій);

10) функція моніторингу різноманітних економічних індикаторів на кшталт індикаторів продовольчої безпеки;

11) охоронна функція відображається в тому, що забезпечується захист економічних прав і законних інтересів України, ії суб'єктів господарювання.

Водночас визначення функцій та загального окреслення компетенції Мінекономіки в напрямі реалізації державної політики у сфері забезпечення економічної безпеки держави недостатньо для дослідження компетенції органів державної влади, а також органів виконавчої влади, органів місцевого самоврядування та громадських інституцій, тому в подальших дослідженнях необхідно з'ясувати компетенцію інших органів шляхом надання характеристики кожного з іiі елементів.

\section{Список використаних джерел:}

1. Советский энциклопедический словарь. Москва : Советская энциклопедия, 1984. 1600 с. 2005. $1728 \mathrm{c}$.

2. Бусел В.Т. Великий тлумачний словник сучасної української мови. Київ ; Ірпінь : Перун,

3. Сліпушко О.М. Тлумачний словник чужомовних слів в українській мові. Правопис. Граматика. Київ : Криниця, 1999. 511 с.

4. Армаш Н.О. Керівник органу виконавчої влади: адміністративно-правовий статус. Запоріжжя : ГУ «ЗІДМУ», 2006. 248 с.

5. Крупчан О.Д. Компетенція центральних органів виконавчої влади. Вісник Академії правових наук України. 2002. № 2 (29). С. 47-59.

6. Нерсесянц В.С. Проблемы общей теории права и государства : учебник. Москва : Норма, 2004. 832 c.

7. Популярный юридический энциклопедический словарь. Москва : Большая Российская энциклопедия ; РИПОЛ КЛАССИК, 2001. 800 с.

8. Панов Н.И. Словарь терминов по теории государства и права. Харьков, 1997. 180 с.

9. Гарбузов В.В. Адміністративно-правовий статус підрозділів внутрішньої безпеки Національної поліції України : дис. .... канд. юрид. наук : спец. 12.00.07. Запоріжжя, 2016. 241 с.

10. Скакун О.Ф. Теорія держави і права : підручник. Харків : Консум, 2001. 656 с.

11. Бахрах Д.Н., Россинский Б.В., Старилов Ю.Н. Административное право : учебник. Москва : Норма, 2007. 816 с.

12. Богданова Н.А. Категория статуса в конституционном праве. Вестник Московского университета. Серия № 11 «Право». 1998. № 3. С. 3-20.

13. Криворучко В.О. Органи виконавчої влади як суб'єкти адміністративного управління. Підприємнищтво, господарство і право. 2018. № 3. С. 95-99.

14. Волинка К.Г. Теорія держави і права : навчальний посібник. Київ, 2003. 240 с.

15. Питання Міністерства розвитку економіки, торгівлі та сільського господарства : Постанова Кабінету Міністрів України від 11 вересня 2019 року № 838. Офіиійний вісник Украӥни. 2019. № 74. Ст. 2588.

16. Про здійснення державних закупівель : Закон України від 1 червня 2010 року № 2289-VI. Відомості Верховної Ради України. 2010. № 33. Ст. 471.

17. Про публічні закупівлі : Закон України від 25 грудня 2015 року № 922-VIII. Biдомості Верховної Ради України. 2016. № 9. Ст. 89. 